\title{
The Roman Catholic Church and Clergy in the Nazi-Fascist Era on Slovenian Soil
}

\begin{abstract}
By Zorica Petrović*
The revisionism of the role the Catholic Church and collaborators had during World War II has been quite a typical approach in Slovenia, as one of the post-transition countries of the former Yugoslavia. With their own interpretation of the causes and consequences of pre-war, wartime and post-war events, the role of the Slovenian Home Guard and the Catholic clergy has been deliberately portrayed for years, as one of naivety and good intentions in the name of home, God, and religion. In relation to that, the aim of this paper is to point out some crucial facts, which are well documented and supported by recorded evidence. An insight into socio-political developments in the Slovenian territory, and the ideological background that conditioned the attitude of the official Church authorities towards representatives of the occupier is, therefore, essential. Also, the paper provides a closer look at the clergy's attitude towards occupying forces and the National Liberation Forces in Slovenian regions, occupied by both the German and Italian agressor, given the time, space and social conditions. The conclusion addresses not only the process of reconciliation, but also the possibility of an alternative for a far more credible moral stance of the Church, in its attempt to be a key element of nation and state sovereignty in the eyes of the people and history in the long run.
\end{abstract}

\section{Introduction}

This paper discusses the role of the Slovenian Catholic church during World War II within all of its variables. The general characteristic of this research is mostly about making logical connections between these crucial points: the Slovenian public opinion on the matter, the impact of the ideologically overpolarized Slovenian media and politics on historical revisions, the co-relation between the Church, the occupiers and the national armed anti- fascist resistance, and unveiling the historical and social context of the clash which ultimately brought to bloodshed with elements of a civil war alongside the liberation struggle.

When it comes to actuality and importance, the topic in Slovenia usually receives a lot of attention during each election time. The collapse of the eastern block and the associated transition brought Slovenia the long anticipated democracy, but it also presented the challenge of how to evaluate recent Slovenian history. On 8 July 1990, one of the first steps towards the reconciliation of the divided Slovenian nation took place in a ceremony in Kočevski Rog, a mass grave site. The Archbishop Alojzij Šuštar, and Milan Kučan, then President of the Presidency of the Federative Yugoslav Republic of Slovenia, both paid respect to the victims of postwar extrajudicial killings: "We are too few in numbers and we live in too harsh of conditions, to ignore the ability of living in a peaceful coexistence, recognition of our diversity, tolerance and respect. We will feel suppressed and will be threatening each

${ }^{*} \mathrm{PhD}$ Candidate, University of Primorska, Slovenia. 
other again, unless we do not set such a life for our goal. ${ }^{11}$ Deep karst caves and abyss of Kočevski Rog are the last resting place of mostly Home Guard ${ }^{2}$ members, who sought refuge in Austria after the defeat of Nazi Germany, but were repatriated to Yugoslavia by the British allied forces.

Mostly with the initiative of right wing parties, especially Slovenian Democratic Party (Slovenska demokratska stranka or shortly SDS) and The New Slovenia (Nova Slovenija or shortly NSi), the topic has been discussed to the point of extreme ideological polarization, where facts or cause-andeffect relationships seem to matter no more. Instead, especially the internet media seem to be repeating the parties' formulations that are literally taken out of the propaganda during $2^{\text {nd }}$ World War. According to some research, the public opinion in Slovenia on these matters shows a different picture, than one proposed by the media and mostly proposed by the politicians. The Institute of Social Sciences (Inštitut za družbene vede FDV) reviews public opinion regularly since 1984 , with results pointing to a different image; most respondents approve of the armed Partisan resistance. The vast majority of the respondents consider post-war mass killings a terrible crime or at least a great political error, but not even ten percent of respondents see the Home Guard anti-Partisan operations as justified. ${ }^{3}$ It seems that in the eyes of collaboration apologists, the history of World War II should become the history of the losers. The Slovenian political right wing keeps reporting the Republic of Slovenia to European institutions for constant use of "totalitarian symbolism"; these allegations refer to Partisan celebrations, including the celebration of Victory day on May $8^{\text {th }}$, when Nazi Germany surrendered to the Allies. ${ }^{4}$

Unfortunately, especially over the last 20 years, the previous research on the recent Slovenian history has been mostly reduced to the ideological clash between the heirs of the former clerical Conservatives on one side, and liberal or Socialist/Communist political options on the other side. Slovenian research work also reflects this attitude. Revisionist historians seem to be prevailing in public discourses, while historians who advocate and justify the values of the national liberation struggle, are often targeted and misquoted by

1. M. Kučan, Spravna slovesnost v Kočevskem Rogu [Conciliation ceremony in Kočevski Rog], https://bit.ly/2KywSpu.

2. After the capitulation of fascist Italy, new auxiliary paramilitary units of Slovenian nationality were formed from the remnants of the White Guard, MVAC and individual antiPartisan groups on the initiative of high ecclesiastical representatives in the Province of Ljubljana. They were armed, trained and paid by the German occupiers and named themselves the Home Guard (domobranci). G. Krajnc, Hoja s hudičem: okupacija Slovenije in kolaboracija, 1941 - 1945 [Walking with the Devil: Slovene Collaboration and Axis Occupation, 1941 - 1945] (Mengeš: Ciceron, 2014); F. Saje. Belogardizem [The White Guard] (Mengeš: Ciceron Press, 2008); S. Grgič, Zločini okupatorjevih sodelavcev, monografija v treh knjigah.1. knjiga: izven borbe pobiti in na druge načine umorjeni, ranjeni in ujeti slovenski partizani [The crimes of the occupier's assistants - monograph in three books. Book 1: killed outside the battle and otherwise killed, wounded and captured Slovenian Partisan] (Novo mesto: Društvo piscev zgodovine NOB Slovenije; Tiskarna Novo mesto, Dolenjska založba, 1995).

3. N. Toš, et al., Vrednotenje preteklosti [Evaluation of the past], https://bit.ly/2Gm $\mathrm{m} 7 \mathrm{Kc}$.

4. G. Krajnc, Hoja s hudičem: okupacija Slovenije in kolaboracija, 1941 - 1945, 2014, 7-9. 
the Church, which attempts to restore its' once leading role in Slovenian public life. The Church and right wing parties constantly accuse other nonrevisionist historians of justifying a totalitarian Communist dictatorship that dominated the Slovene and Yugoslav political scene for almost half a century.

According to the Canadian historian of Slovenian origin Gregor Kranjc, the revision had already started to form within the more liberal circle of Yugoslav Communists. Some of them were "tolerated" dissidents and historians, who were ultimately encouraged to fully addressing the subject by the formal independence of Slovenia. The emerging liberal-democratic approach opened up some issues of political, ideological and social heterogeneity in the group that was labeled with the word "collaborators" by the Communist authorities. In addition to the black-and-white view of the topic, gray shades began to appear, but the recent literature on the topic is mainly represented by a growing number of apologists who portray all participants of collaboration solely as misunderstood patriots and fierce fighters against communism, while the Liberation Front (Osvobodilna Fronta or shortly $\mathrm{OF}$ ) has been labeled as a solely Communist organization, whose only goal was to take over the political power. ${ }^{5}$

The present political climate in Slovenia makes it almost impossible to objectively investigate and research the cause-and-effect connections, without making it an ideological issue. The right wing parties in particular use the aggressive rhetoric that sometimes goes beyond all the limits of good taste, when emphasizing their alleged victim's position. The reason for this investigation is to primarily draw attention to those historical facts that oblige both sides to a critical and objective approach by keeping a reasonable distance without emotional involvement. It is clear, however, that the interwar generation is still present and that interwar and postwar horrors caused profound wounds. But when addressing and writing history, the tendency to abuse this situation, should be largely avoided.

The intention of this paper is to address the root of the problem, which is allegedly also being a primary objective of the Slovenian right wing, guided by the Slovenian Catholic Curch. Therefore, this paper's central research question is the extent of responsibility the official Catholic Church in Slovenia had during World War II in the genocide, implemented against the Slovenes by the Axis forces. By presenting the attitudes and actions of a few individual priests during the occupation, this paper will also answer the question if the official Catholic Church had a possible alternative. It is necessary to recall a self-critical and objective dialogue in the Slovenian public arena in the light of current issues. Moreover, given the rise of nationalism in the last few years all over Europe, it is essential that, even in a wider context, we remember that the foundation of the existing European Union is built on the fight against Fascism and Nazism. All resistance armed units across the entire occupied Europe, regardless of their political orientation, were a part of this armed struggle. The main academic-reasearch problem that has to be investigated is particularly the correct use of terms like "collaboration" and "civil war" in the appropriate context. The topic of investigation is therefore the relationship of

5. Ibid., 46-53. 
the official Slovene Church with the occupier on one hand, and with the Liberation Front on the other hand. In order to understand this relationship, it is necessary to clarify the social and historical background of the Slovene political space and national awakening in the 20-ies and 30-ies. It is also necessary to address the role of priests in auxiliary quisling units, in contrast to the role of priests in the Partisan movement. For a complete illustration of the rather complex situation, it is also necessary to compare the position of priests in the German and Italian occupying zones. The attitude of the Liberation Front regarding the Church will also be presented, as well as the consequences that the collaboration had for the position of the church after the war. The methodology used in this research will base mainly on evaluating, comparing and analyzing the written literature from both ideological poles, by forming an original statement also through leaning on original documents and sources.

\section{Historical Background of the Schism in the Slovenian Society and Politics}

During the 19th and 20th centuries, there was a growing inquiry into the centuries-old conservative Christian social order. Certain behavior patterns handed down from generation to generation as tradition or cultural heritage were becoming less and less self-explanatory. As the developing science of sociology and general industrialization of society increased in daily social life, the historically stable ecclesiastical authority faced a serious contender. As a result, the mass awareness had to be maintained through humble acceptance of God's natural order; therefore, fear of God's punishment seemed to curb "dangerous" ideas and any desire to change the existing situation. Bourgeois liberalism was still in its infancy. However, it represented a great danger for the Church because of its philosophical perception of man as an independent individual on one side and man as a conscious member of the (classless) collective on the other side. ${ }^{6}$

After the adoption of the national program Unified Slovenia (Zedinjena Slovenija), the disruption in the Slovenian national movement originated primarily from the broad opposition between Catholic Conservatives and the Liberals. It wasn't until the so-called "era of harmony" (doba slogaštva) that the Catholic fraction took in consideration the idea of the Slovenian national consciousness. They only agreed to this mindset, after the Liberals decided to sacrifice the public defense of their views, accepted some Catholic slogans, and finally joined forces with the Slovenian Catholic wing against the pressures of German assimilation. ${ }^{7}$ Moreover, national consciousness was rather of

6. I. Jan, Škof Rožman in kontinuiteta : zahteva po škofovi rehabilitaciji - ponoven izziv resnici [Bishop Rožman and continuity: the demand for bishops' rehabilitation - a new challenge to the truth] (Ljubljana: self published, 1998), 39-51; E. Pelikan, Akomodacija ideologije političnega katolicizma na Slovenskem [The accommodation of the political Catholicism' ideology on Slovenian soil] (Maribor: Obzorja Press, 1997).

7. A. Pančur, Leto 1848 in oblikovanje programa Zedinjena Slovenija [The year 1848 and the forming of the programme Unified Slovenia] (Ljubljana: Institute of Contemporary History, 2005), 24- 31. 
secondary importance to the prevailing Catholic mentality. Bishop Anton Mahnič, in particular, kept on attacking anything that was not in accordance with his radical statements and practices of Catholic principles. To him, religion was the fundamental principle that transcended both national consciousness and the country's affiliation with the Church. With the support of Pope Leo XIII, this extreme Catholic militancy eventually led to the inevitable schism within the Slovenian political arena. ${ }^{8}$

In the 1930-ies, the Christian movement experienced a significant shift. The global economic crisis had not spared Slovenia. In 1931, Pope Pius XI issued the encyclical Quadragesimo Anno, in order to promote the renewal of the Christian movement not only on the religious level but also on economic, socio-political and educational levels. Catholic peasant masses were rather responsive to new forms of Catholic activism during the dictatorship of Yugoslav King Alexander. Slovenian theologian and Catholic philosopher Dr. Aleš Ušeničnik believed that the solution of social issues lied particularly in the implementation of natural and Christian moral principles as wells as through consistent rejection of liberalism, socialism, and communism. With the establishment of Catholic Action ( Katoliška akcija or shortly KA), the Church aimed mainly at young people who would help creating "a new Christian society". The activity of the KA members eventually became so radical in their Christianization, that it averted not only secular, liberal, and Marxist-oriented people, but also a lot of individuals within the Catholic wing itself ${ }^{9}$.

Although the schism did occur within the Catholic political fractions regarding the social doctrine of the Church, the Catholic right-wing transformed their political activism into an authoritarian ideology. While in principle this renewed form of Catholic activism could not be directly accused of racist theories, it remained closely linked to fascism because of its authoritarian nature, anti-communism, anti-Semitic rejection of the class struggle, and the imposition of corporate social arrangements. All these characteristics were underlined by the principle of subsidiarity, the doctrine of the Church being omnipresent in society, politics, and education. Similarly, Fascist principles also permeated all spheres of public and private life. In the period between the two wars, the Slovene Catholic tradition intensified its struggle with communism, by faithfully following the hysteria of the Catholic Church throughout Europe. Their ideological stance is best illustrated by the writing of the Slovene journalist in May 1933: "Fascism has undoubtedly many attractive features, including Catholics. We remember its efforts for a moral supremacy, its suppression of the class struggle and the establishment of a corporatist state. Whatever is positive in Fascism is taken from Christianity, and, of course, Fascism must necessarily be part of the anti-Bolshevik front.

8. E. Pelikan, Akomodacija ideologije političnega katolicizma na Slovenskem, 1997, 2139.

9. G. Krajnc, Hoja s hudičem: okupacija Slovenije in kolaboracija, 1941 - 1945, 2014, 63 75 . 
$" 10$ Historian Niall Ferguson sarcastically wrote that "he could fill the whole book only with a list of all priests who only sympathized with fascism." ${ }^{11}$ Political Catholicism was particularly active in the following: issues between church and state, favoring church marriage before a civil one, in relation to the Sokol pan-Slavic gymnastic movement, and in school policy. The Divini Redemptoris encyclical in 1937, which attacked godless Communism, personified the state of mind of the Catholic right wing, whose explicit goal was a complete re-Catholization of public and private life. ${ }^{12}$

Bishop Rožman faithfully followed the anti-Communist principles of Pope Pius XI. For the 1940 Code of the Ljubljana Diocese, he used the most frequently quoted statement from the Encyclical Divini Redemptoris: "Communism is something bad in its essence, and therefore no one, who cares about Christian civilization, should ever cooperate with it." Pius XI. underlined his position with his response to the outbreak of the Spanish Civil War. His successor cultivated the same fear of Communism, and subsequently, the Vatican showed a rather dangerous example of cooperation with European dictators. The Vatican agreement with Mussolini in 1929 and Hitler in 1933 was presented only as a preservation of the autonomy and religious freedom of the Holy See. This is how Vatican tried to keep control of the ecclesiastical hierarchy in Italy and Germany. The 1929 Lateran agreement, in fact, guaranteed the passivity of priests in public socio-political discourses in exchange for compulsory religion in elementary schools, the presence of a cross in classes, and the legal equality of Catholic private schools with public ones. Mussolini was thus enthusiastically supported by the Italian clergy in the next election of the same year. ${ }^{13}$

Hitler, in his concordat in 1933, similarly promised German Catholics greater autonomy and greater validity of canon law. In Vatican circles, a rough Hitler clash with Communists in Germany was largely approved bumper against Bolshevism. Hitler however insisted on the complete withdrawal of the Church from the social and political scene, which enabled him to completely neutralize the opposition in Germany, represented by the Catholic party Zentrum. In 1937, the Pope reacted to Hitler's constant violation of the concordat, with the encyclical Mit Brennender Sorge (With a burning concern). But the legacy of his successor, Pius XII, is more problematic. And as such, it remains the cause of the overwhelming debate. However, due to its obsessed anti-Communism, the Vatican was ready to cooperate with European Fascist dictators for the preservation of the privileges of the Church. As such it was a dangerous example for both the Slovenian Catholic Church and the leading SLS party. ${ }^{14}$ $72-78$.

10. G. Krajnc, Hoja s hudičem: okupacija Slovenije in kolaboracija, 1941 - 1945, 2014,

11. N. Ferguson, The war of the world: twentieth century conflict and the descent of the west (New York: Penguin, 2007) 231.

12. E. Pelikan, Akomodacija ideologije političnega katolicizma na Slovenskem, 1997, 80 95.

13. G. Krajnc, Hoja s hudičem: okupacija Slovenije in kolaboracija, 1941 - 1945, 2014, $76-77$.

14. Ibid. 


\title{
Prominent Representatives of the Slovenian Catholic Church in Relation to Ethnicity and Social Dilemmas
}

\begin{abstract}
"We are closer to the German and all other Catholics, than to Slovenian liberals. And if we ever had to choose among the alternatives: what do you want to sacrifice - faith or ethnicity? We shall answer: let us maintain our faith!" (Bishop Anton Mahnič) $)^{15}$
\end{abstract}

At first glance, it seems that the Catholic wing was much more unified than the Liberals. However, it also consisted of internal divisions. The bone of contention lay in the different degrees of political flexibility of some of its most prominent representatives. This flexibility was reflected in the ability of more visible Church officials to adapt the social doctrine of the Church to modern social flows. Thereby, the political Catholicism proved to be quite ambivalent, depending on the individual representative's degree of (un)readiness for the decline of the Church's influence in society and the country.

On the one hand, the rural population was dominated by a strong church hierarchy, which, from the local parish priest, to the bishop, had not only spiritual but also secular and political influence on the people. But the influence of the Slovenian political and religious elite with the modernization of Slovenia in two decades between the two world wars faded rather drastically; the stereotypically subdued rural way of life has changed. According to conservatives, urban centers have become the advocates of immoral and nonreligious ideologies, with political and ideological opposites being followed by the generation gap. Former Partisan Rudolf Hribernik - Svarun remembered his father's anger because he had been hanging out of the Communists instead of going to Sunday Mass: "Don't even think about explaining to me the things that you are taking from God knows where. The last time I tell you, you will go to church, or you will not eat again by my table!"16

The nature of the schism in the Catholic wing is best expressed in questions of national identity, popular sovereignty, and parliamentary democracy. ${ }^{17}$ However, in fundamental issues of their political accommodation, Slovenian Catholicism (unfortunately) failed to take over the flag of national awakening fast enough in their hands. When discussing the Church (religion) in relation to ethnic issues, performed by most prominent Catholic players, we cannot ignore Bishop Anton Mahnič. Due to his crucial role in radicalizing Catholic activism in the Slovenian political arena, which in its most perverse version provoked a fratricidal war at the time of Nazism, his contribution to the socio-political climate in Slovenia is worth a closer look.

15. A. Mahnič, "Brezglavnost slovenske politike- posnemajmo češke katoličane!" [The headlessness of Slovenian politics - let's take the Czech catholics' example!], Rimski katolik, no.1(1891): 84.

16. G. Krajnc, Hoja s hudičem: okupacija Slovenije in kolaboracija, 1941 - 1945, 2014, 79.

17. E. Pelikan, Akomodacija ideologije političnega katolicizma na Slovenskem, 1997, 12-18. 
Bishop Anton Mahnič (1850 - 1920) published his extreme radical views in the Catholic journal "The Slovenian" (Slovenec), and in 1888 he started to openly attack the inside dissidents, especially Catholic liberals, by issuing a journal called "The Roman Catholic" (Rimski katolik). In relation to ethnic issues, Mahnič faithfully personified the general state of mind of the Catholic Church. The hysteria in the Vatican was rather evident ever since the unification of Italy. Pope Pius IX. in his Syllabi of 1864, flatly condemned everything that truly or supposedly compromised the power and authority of the Church: Communism and Protestantism alike, along with the independence of education and culture in state institutions. According to Mahnič, the "Unified Slovenia" program was merely a hopeless attempt to achieve ethnic autonomy: "...because we Slovenes may not hope for any particular political future, we are but a small nation split politically. Most of what we should hope for is to achieve our linguistic rights in public life" ${ }^{18}$. At the same time, Mahnič criticized the Unified Slovenia program as a "pagan separation of nations " and lack of historical basis, and summed up his priority order in defining Slovenehood with the conclusion: "Our henoticon, Slovenes, is the Catholic idea: whole, one, indivisible! This is our unified Slovenia. Everything else is - liberal utopia!" 19

Dr. Janez Evangelist Krek (1865 - 1917), the contemporary of Mahnič, also received his doctorate in theology in Vienna and taught at the Ljubljana Faculty of Theology. At the beginning of his priestly life, he dealt with the national question much like Mahnič but has gradually adapted his views to the increasing ethnic tensions within the "prison of nations", as the AustrianHungarian empire was also named among its' non-German subjects. $\mathrm{He}$ began to call for genuine equality of Slovenes in the field of educational and state institutions overall and became a visible member of the young generation of Christian Socialists. Unlike Mahnič, Krek had a different priority order: the nation, not the state, was ranked immediately after the Church. With that, he gave Mahnič an obvious sign. The only solution for Austria, in the long run, was to openly address the social and national issues. For Mahnič, who viewed the role of the Catholic Church as a universal prescription for any problem, this was a step forward to apostasy from the faith. ${ }^{20}$

Dr. Aleš Ušeničnik (1868 - 1952), philosopher and theologian with a double doctorate, and one of the first professors at the Theological Faculty in Ljubljana, was considered a successor of Bishop Mahnič in many ways. Likewise, he tried to maintain at least the apparent leading role of Catholicism before the nation in public discourse. From his works, it is evident that this was his primary concern, while his attitude towards the national question can best be reflected in his belief, that every conscious Slovenian must also be a conscious Catholic. Such a change of heart within the Catholic political

18. A. Mahnič, Revolucionarno gibanje na Ruskem [Revolutionary movement in Russia ], Rimski Katolik, no.1(1891): 286.

19. A. Mahnič, "Slovstvo" ["Language"], Rimski Katolik, no.1(1889): 418.

20. E. Pelikan, Akomodacija ideologije političnega katolicizma na Slovenskem [The accommodation of the political Catholicism' ideology on Slovenian soil] (Maribor: Obzorja Press, 1997), 30-35. 
activism became a challenge for the Liberals in the Slovenian socio-political space. $^{21}$

\title{
Occupation of Slovenian Territories and Assimilation Measures
}

\author{
"Machen Sie mir dieses Land wieder Deutsch!- Make this country German \\ again for me!" (Adolf Hitler about occupying Maribor in 1941).
}

In April 1941, Hitler divided Slovenia between three occupiers; these division lines also created actual state borders. Germany occupied Slovenian Styria (Štajerska), Upper Carniola (Gorenjska), Carinthia (Koroška) with Mežica Valley, and the northern part of Dolenjska region. Italy got the remaining major part of Dolenjska, Notranjska, and Slovenian capital city Ljubljana, while Hungary seized Međimurje and Prekmurje flatland. As the newly drawn borders were firmly consolidated and almost airtight protected by the Axis powers, that meant a deep wound in the cultural, economic and existential life of Slovenes. Most of the leading Slovenian administrative staff were quickly replaced by German, Italian and Hungarian officials. ${ }^{22}$

In the eyes of all three of the occupiers, the fate of the Slovenian nation was nothing less than the whole ethnic unit to be erased from the occupied territories. In planning and implementation of assimilation measures, German Nazism was by far the most energetic and efficient one. The Nazi plan was the eradication of Slovenes as a state-national entity, which had to be achieved by mass deportation of Slovenes and mass resettlement of Germans, along with Germanising the rest of the population. According to Heinrich Himmler, every third Slovenian was to be evicted from the area occupied by Germans, so the categorization of the population started immediately. The German authorities saw the potential threat mostly in educated Slovenians (teachers, priests, teachers) as well as politically and racially controversial individuals. ${ }^{23}$ On the whole, around 20,000 Germans eventually managed to settle in the Slovenian territory, coinciding with the Nazi policy of "Heim ins Reich!" This plan of Heinrich Himmler, named Generalplan Ost, also included Slovenia, and designed the forced eviction of as many as 30 million people in Eastern Europe, in order to make room for the 11 million of German colonists. The elimination process included establishing the following: assimilation of organizations $^{24}$ (Steierische Heimatsbund, Kärntner Volksbund); the Germani-

\section{Ibid.}

22. T. Ferenc, Nacistična raznarodovalna politika $v$ Sloveniji v letih 1941- 1945 [The Nazi national and assimilation politics in Slovenia in the years 1941-1945] (Maribor: Obzorja Pres, 1968), 133-147; G. Krajnc, Hoja s hudičem: okupacija Slovenije in kolaboracija, $1941-1945,2014,87-95$.

23. T. Ferenc, Okupacija slovenskega ozemlja [The Occupation of Slovenian Territory], in Slovenska novejša zgodovina 1848 - 1992 ed. J. Fischer (Ljubljana: Institute of Contemporary History, 2005), 581-601.

24. T. Ferenc, Nacistična raznarodovalna politika $v$ Sloveniji v letih 1941- 1945 [The Nazi national and assimilation politics in Slovenia in the years 1941-1945] (Maribor: Obzorja Pres, 1968), 731-821. 
sation of personal and local names; destroying the Slovenian press; and the confiscation of Slovenian assets. The Nazi authorities did everything in order to follow the guidelines from the public decree in 1941, which stated that no later than five years from then, the German language would apply exclusively in the occupied area. ${ }^{25}$

The German civil administration started negotiating with the NDH government, although Hitler was initially opposed to exiling Slovenes to Croatia. His Foreign Minister Joachim von Ribbentrop convinced him though, that this would enable the Ustasha government to expel more Serbs from Croatia. This opinion was based on the belief that it would be easier for Catholics than Orthodox people to assimilate among the Croats. The NDH government actively cooperated with the civil administration for the Lower Styria; however, a draft of the agreement on the transfer of Slovenians to Croatia remained unsigned. Instead, the German delegation in Zagreb and the Ustasha government exchanged only verbal notes as a mutual consent to deportation. $^{26}$

According to the Nazi plans, the deportation of Slovenes from the occupied Gorenjska (Carniola) and Lower Styria Region was supposed to take place in three organized waves. The first wave had foreseen the expulsion of politically most dangerous individuals: politicians, scholars and teachers directly to Serbia, while Roman Catholic priests were to be expelled to Croatia. The same number of Serbian Orthodox priests with families would be deported to Serbia. By that agreement, 217 Slovenian priests from Lower Styria were transported directly to Zagreb. Transportations from Gorenjska went through Ljubljana and stopped there briefly, but citizens reacted with turbulent demonstrations to the deportation of their fellow countrymen. Since Italian military forces were unable to control the situation, German transports had to pass through Ljubljana without a pit stop. The Liberation Front of Ljubljana printed the following pamphlet:

"The latter nights have witnessed the most terrible tragedy that could hit a nation. Trains full of our best Slovene families, which the barbaric Germany tore out of the country and sent to exile, drove through Ljubljana every night. Hundreds of empty Slovenian houses are waiting to be occupied by German immigrants. You, white Ljubljana, you who are the heart of Slovenia, have felt all the pain of the Mother Slovenia, whose children were torn off her chest. In these nights, you sent thousands of your children along the railway, to say goodbye to the exiles." 27

Italian Fascist authorities were initially much more indulgent because they took into account a rather inhospitable spirit in the occupation zone. In the field of civil law and non-political criminal cases, the courts continued to function with the Slovenian personnel next to the Italian, and temporary bilingualism was introduced. However, Italian Fascism had already conducted

25. Ibid.

26. Ibid., 233-234.

27. Ibid., 235, 245-248. 
its own rehearsal in the field of systematic cultural genocide. They first started on the Littoral (Primorska territory): the repression of cultural - educational press and the burning of Slovenian language books, prohibiting the use of Slovenian language in public life, churches and schools, and the Italianization of Slovenian personal and place names. ${ }^{28}$ It was however in the occupied Ljubljana, where Italians have shown their true attitude: they surrounded the whole city with a ring of barbed wire. In obtaining sympathy of the population, they focused primarily on schoolchildren, by establishing Fascist youth organizations and introducing the Italian language in schools. Similarly, the Slovenes in Prekmurje region were declared "Vende" by both assimilation and persecution: Hungarian occupying forces abolished all Slovenian schools and introduced education in Hungarian education, Slovenian youth were forced to enroll in the paramilitary youth organizations, and men were mobilized in the Hungarian army. Teachers, priests, and colonists who had fled the Littoral due to Italian fascist persecution, were taken to the concentration camp Szarvar. ${ }^{29}$

\section{The Official Church and Crimes of Collaboration against the Civilian Population}

"It is permissible to announce meetings, decisions, actions and individuals to those who fight against communism, or to the representatives of authorities ... It is not ugly to announce criminals to the authorities . . . Anyone who informs the authorities is not a traitor but does a good job of charity for their neighbor by protecting them from accidents and preventing public misfortune. God, natural, human and international law require notification and delivery of criminals, dangerous to the public. Duty bounds under sin! "

(Dr. Janez Kraljič, Bishop's clerk of the Catholic Action) ${ }^{30}$

The Catholic Church has not experienced the same fate everywhere nor as an institution, neither as a communion of believers and pastoral leaders. German reprisals involved in particular the persecution of Slovenian Catholic priests, who were considered important keepers of Slovenian culture and national unity, with an ideology opposing Nazism. Priests were subjected to special attention in the German occupation zone: The German police officers humiliated and tortured them in various ways. Priests had to empty the latrines with their bare hands, they were forced to assist in demolishing the Maribor Orthodox Church, and they were brutally punished for bizarre violations of the camp order. Priests were imprisoned in concrete bunkers, where they were severely beaten, often having their ribs broken or their teeth knocked out, and they were often forced into excessive physical exercise. By the end of May

28. M. Klemenčič and M. Žagar, The former Yugoslavia's diverse peoples: a reference sourcebook (Santa Barbara, California: ABC Clio, 2003), 164 - 168.

29. Ibid.

30. F. Saje, Belogardizem, 2008, 126. 
1941, in the Slovenian Styria camps, 130 out of approx. 1300 Slovenian prisoners were priests. Himmler's instructions specified that exiling teachers and priests as representatives of the Slovenian intelligence, was a priority. ${ }^{31}$

The Nazis attributed to Slovenian priests a good part of the responsibility for the prevalence of Slovenian national consciousness in Styria and Carinthia. The use of Slovenian language in the churches was abolished: due to the resistance of Bishop Ivan Tomažič in the Lavantine diocese, this measure had to be declared by the German civil administration. The answer to the "anti-German behavior" of Church representatives in Styria region, was the confiscation of most church property, and the closure of the Theological Seminary schools in Maribor. Most of the Slovenian Catholic priests in the German occupying zone were sent to exile: the Gorenjska region was particularly affected, where only 15 to 20 elderly priests were left in 141 parishes. ${ }^{32}$ German priests, who were entrusted with the task of Germanisation, followed the orders rather vaguely and ignored deliberate Germanisation for the largest part. ${ }^{33}$

In 1941, a secret military organization called The Slovenian Legion (Slovenska Legija) was formed on a proposal from the Slovenian National Party (Slovenska ljudska stranka). By the end of the same year, its' founders started an active campaign:

"Suppress any partisanship in particular . . Any other solution is a real betrayal!" 34

Anti-Communist propaganda included printing brochures and books, management of religious organizations, and mostly sermons in churches. Statements of priests in the pulpits contained even attacks on the mothers of partisans: "See ye mothers, what Judas you have raised. You thought that you had raised good kids, but instead, you raised devils. (...). Damn should be the one mother who gave birth to a son partisan because she gave not birth to a child, but to a devil!" 35

France Strle was 16 years old, when the Italians and members of the White Guard killed his father. This is how his written reply to Bishop Lenich and his praise of Bishop Gregorij Rožman:

"My mother was a deeply religious person. Three months after my father's death, she was took my 11-year-old brother, Janko, to the church for his Chrismation. Then, the immense suffering for the loss of her husband was joined by terrible humiliation; she heard the poisonous words of Bishop Rožman from the pulpit, who demanded that Partisan mothers should

31. T. Ferenc, Nacistična raznarodovalna politika v Sloveniji v letih 1941- 1945 [The Nazi national and assimilation politics in Slovenia in the years 1941-1945] (Maribor: Obzorja Pres, 1968), 176- 198.

32. T. Štefanec, Druga svetovna vojna - nasilje, žrtve, upor [Second World War: violence, victims, rebellion] (Ljubljana: self-published, 2011), 21-23.

33. Ibid.

34. F. Saje. Belogardizem, 2008, 157.

35. Ibid., 162-173. 
leave the temple of God. She left the church and many other Partisan mothers with her." Parishioners were encouraged to spit in the faces of partisan family members, and to pass information on partisans and kill them, which was no sin at all. ${ }^{36}$

The Slovenian Legion intelligence service included chaplains among their employees as well. They reported to their district leaders information on suspects among the population, and that has resulted in arrests, internment, torture, interrogation and shooting hostages. ${ }^{37}$ A local Home Guard detachment, for example, did not know that Franc Bukovec - Miro from Gradišče near Škofljica was a partisan activist. During his interrogation, he was told why he had been captured:

"We do not know you, but Pastor Ciril Milavec told us that before the war you never went to the Sunday church service and that we should not let you go out of here alive."

During Italian occupation, Slovenian Catholic priests actively participated in the Legion of death (Legija smrti) within the MVAC (Militare Voluntaria Anticomunista /Anti-Communist Volunteer Militia). The Italian IX. Army Corps officially appointed 10 Chaplains, paid by the Italian army. ${ }^{39}$ One of them was also Father Radovan Šinkar. The Home Guards complained about his lack of care for prayer, more soldier than priest behavior, and that he prefers armed action in the field over confessions and catechesis. ${ }^{40}$ The Home Guards and their chaplains, who committed atrocities in the church of St.Urh near Ljubljana, deserve special attention for their bestiality and cruelty over captured partisans and their relatives. The most notorious was the Chaplain Peter Križaj, whose understanding of godly service was rather peculiar. ${ }^{41}$ The book Palm Trees of Martyrdom (Palme mučeništva), dedicated to killed or otherwise persecuted Slovenian priests during the WWII, mentions his activities during the war briefly only as a spiritual care for the inhabitants of Bizovik, members

36. I. Jan, Škof Rožman in kontinuiteta: zahteva po škofovi rehabilitaciji - ponoven izziv resnici, 1998, 157.

37. F. Saje, Belogardizem, 2008; I. Jan, Škof Rožman in kontinuiteta : zahteva po škofovi rehabilitaciji - ponoven izziv resnici, 1998.

38. J. Vidic, Po sledovih Crne roke [Following the traces of the Black Hand] (Ljubljana: Borec Press, 1975), 468.

39 J. Kos. Druga pričevanja [Other testimonies], in Škof Rožman v zgodovini, ed. J. Pleterski (Ljubljana: Društvo piscev zgodovine NOB Slovenije - The Association of the Slovenian National Liberation Front History Writers, 2008), 116.

40. F. Saje, Belogardizem, 2008, 312.

41. During a mass at St. Urh, he participated in the beating and killing of an elderly widow, confessing her just before her death, and peacefully carried on with the mass on after she died. When a woman from a nearby village was begging the Chaplain for her life and the sake of her children, kneeling under the Cross, he refused her plea with the sentence: "I can save your soul, but not your life!" I. Jan, Škof Rožman in kontinuiteta: zahteva po škofovi rehabilitaciji - ponoven izziv resnici, 1998, 177. 
of village guards ${ }^{42}$. There is not one single word about his involvement in the torture and killing of captured Partisans and members of the Partisan families, and his arrest is presented as a "great calvary". All other priests, who actively partecipated in denouncing, capturing, torturing and even killing Partisans and their family members, are also deliberately presented as mere benevolent martyrs. Nevertheless, this book in description of Chaplain Peter Križaj also confirms his statement during the trial in 1945: "I only did what I was told to do by His Excellency Bishop Gregory Rožman and Holy Father the Pope." 43

In the winter of 1941, the Liberation Front leadership addressed Bishop Rožman directly for the first time, $z$ with a request to prevent the clergy from acting against the national resistance. As there was no response from Rožman to any request and subsequent invitations to a meeting, pastor Metod Mikuž also interceded with the bishop, but without success. In February 1943, under epistles addressed to Pope Pius XII, the Christian Socialists within the Liberation Front wanted to inform the Vatican on the views of Catholics who have joined the Liberation Front. That was their last attempt to straighten out things with Bishop Rožman. ${ }^{44}$

After the capitulation of Italy in 1943, the Ljubljana region was occupied by the Germans. On the proposal of General Leon Rupnik and Bishop Rožman, the German general in charge Erwin Rösener, established the Slovene Home Guard from the remnants of the dismembered White Guard and some Chetniks. Catholic assemblies were carried on smoothly even under German occupation, for Bishop Rožman defined the Home Guard as a legal authority, which had to cooperate with the occupying forces in self-defense. In that way, he tried to sketch the role of Home Guard merely as a virtual collaboration in the light of the ideological struggle against communism. ${ }^{45}$ This is why he never publicly condemned these anything but Christian statements in the Home Guard press, printed by the diocesan curia:

"In the name of Christ's wounds may fall the partisan!"

"... Do not forget that even the partisans have an immortal soul for which Christ shed his blood on the cross. At the same time, when killing their bodies, you are saving their souls!"46

42. Village guards were auxiliary troops, encouraged and organized by local priests to prevent Partisan raids. Soon after being formed, they joined the head organisation of the MVAC under the wing of the Italian army. B. Repe, S puško in knjigo: narodnoosvobodilni boj slovenskega naroda 1941 -1945 [With a rifle and a book :the national liberation struggle of the Slovenian nation 1941-1945] (Ljubljana: Cankarjeva založba Press, 2015).

43. I. Jan, Škof Rožman in kontinuiteta: zahteva po škofovi rehabilitaciji - ponoven izziv resnici, 1998, 172- 177; A. Pust, Palme mučeništva: ubiti in pomorjeni slovenski duhovniki, redovnii in bogoslovci in nekateri verni laiki [Zdravko Reven and Božidar Slapšak, Palm trees of martyrdom: killed and murdered Slovenian priests, monks and theologians and some religius laics] (Celje: Mohorjeva družba press, 1994).

44. T. Štefanec, Druga svetovna vojna - nasilje, žrtve, upor [Second World War: violence, victims, rebellion] (Ljubljana: self-published, 2011), 24-25.

45. G. Krajnc, Hoja s hudičem: okupacija Slovenije in kolaboracija, 1941 - 1945, 2014, 197-198.

46. F. Saje, Belogardizem, 2008, 165-172. 


\section{Catholic Priests in the National Liberation Struggle}

As harshly as Slovenian priests were persecuted in the German occupying area, the greater tolerance they encountered within the Italian military administrations. Undoubtedly, the reasons lie in the unique relationship between the Italian fascist regime and the Vatican Holy See, and the previously mentioned links between fascism and orthodox Catholicism. ${ }^{47}$ The Fascist authorities particularly emphasized the anti-Communist political stance of the Slovenian National Party (SLS), fully regulated and influenced by the Slovenian Catholic Church, and this justified the entire collaboration between the Fascist civil administration and local authorities in Ljubljana. This was especially evident in the relationship of the Bishop Gregory Rožman with the Italian authorities. His example was crucial for many priests in the Province of Ljubljana. Nevertheless, many priests developed a sympathy for the Liberation Front and the emergence of the first Slovenian Partisans. The Liberation Front leadership was struggling to attract as many Catholic priests as possible, to an armed struggle; the Christian Socialists and the Communist Party of Slovenia (Komunistična Partija Slovenije) were particularly active in this attempt. In addition to the importance of an all-national fight against the occupiers, they also highlighted the statements of principle about religious freedom, based on the Soviet constitution of $1936 .{ }^{48}$ The response of the clergy, however, was not as massive as mainly Christian Socialists have hoped. Because of the increasingly evident dominance of the Communist Party within the Liberation Front, and sharp Italian repression in response to Partisan armed attacks, many priests changed their mind about joining the Liberation Front.

In spite of the athrocities, commited by the Catholic priests within the Home Guard in the Ljubljana Province, there were quite a few priests, whose example and attitude prevented the general public opinion from fully demonizing the Catholic clergy in their regard to the occupier. ${ }^{49}$ According to one of the recorded testimonies, Pastor Urbanec and Pastor Lovšin openly rebelled against forming of the Home Guard strongholds in their own parishes. The latter even voluntarily joined his fellow countrymen for deportation to an Italian concentration camp after the mass arrests, but the Italians sent him back home. The third meeting with the Italians was fatal for him, for he suffered a stroke due to extreme stress. Pastor Urbanec has repeatedly contributed money for the operation of the Liberation Front and refused vouchers to enforce repayment after the war, offered by the Partisans, by stating that he contributed as a Slovenian. When a deeply religious elderly woman asked him, whether to let her sons join the Home Guard, he responded: "You should not let your sons go there to fight against their own brothers." In 1944, on the day of the

47. P. Davies, Nevarna razmerja: kolaboracija in druga svetovna vojna [Dangerous Liasions: Collaboration and World War Two] (Ljubljana: Modrijan Press, 2010), 30-32.

48. T. Štefanec, Druga svetovna vojna - nasilje, žrtve, upor, 2011, 21-22.

49. G. Krajnc, Hoja s hudičem: okupacija Slovenije in kolaboracija, 1941 - 1945, 2014, 281 - 287. 
Assumption, a part of the partisan Dolomite Detachment also joined the mass of pastor Urbanec. ${ }^{50}$

Dr. Anton Trstenjak (1906 - 1996), a prominent Slovenian psychologist and theologian, recorded in his memoirs how Bishop Ivan Tomažič (1876 1949), reacted to the idea of forming the Home Guard in the Lavantine Diocese:

"When Rožman, the Bishop of Ljubljana, approved the formation of Home Guard, his emissaries were also sent to Maribor to ask the Bishop of Maribor for his support of forming Home Guard detachments, as well. But Bishop Tomažič resisted: "What, you want to bring to my diocese the evil, that you spread in your own Diocese of Ljubljana? As Bishop, I strongly forbid it! You may go! "And he showed them the door. He literally told me that himself. Therefor, Bishop Tomažič had quite a different position on the matter. Thank God!... Consequently, there was no Home Guard in Styria, people weren't killing one another and there was no mutual hatred, even if someone accidentally happened to be a member of the Home Guard. This easily happened because I know people who had been confronted with the choice of whether to be mobilized into the German army or join the Home Guard, and either of these two choices was a hard one...Jesuit Father Cerar wrote a book with the title "A slightly different Partisan" His Jesuit brethren are now reading this book and do not like it too much. There's a thought written in it, a true one but quoted by no one: the Home Guard had sinned against the gospel with their fight in the name of Christ. ${ }^{151}$

When priest Dr. Method Mikuž joined the partisans, he drew a lot of attention. As a religious clerk in the Partisan army headquarters, his task was to enable and perform religious services among Partisans and civilians. ${ }^{52}$ Bishop Rožman subsequently suspended him until the end of the war, when he was allowed again to perform the mass in Ljubljana cathedral. Dr. Mikuž was a member of the Slovenian delegation, who attended the second session of AVNOJ (Antifašističko vijeće narodnog oslobodjenja Jugoslavije or AntiFascist Council of the National Liberation of Yugoslavia) in Jajce in 1943. Mikuž also succeeded in preserving the All Saints Day as a national holiday, and he also vigorously raised his voice against the political process towards a dissident Narte Velikonja and tagged the verdict as "Juridical crime." 53

The body of official clergy representatives in the Partisan resistance was established by the Liberation Front in 1943, to allow the "satisfaction of

50 T. Štefanec, Druga svetovna vojna - nasilje, žrtve, upor, 2011, 20-23.

51 S. B. Kucler, "Slovenians are too immature for politics: the conversation with dr. Anton Trstenjak, a psychologist-researcher and theologian, author of numerous scientific and popular books that decisively shaped the level of cultural consciousness of Slovenes during the decades after the Second World War", Glas Slovenije, 1994, no. $28: 9$

52. G. Krajnc, Hoja s hudičem: okupacija Slovenije in kolaboracija, 1941 - 1945, 2014, 71; T. Štefanec, Druga svetovna vojna - nasilje, žrtve, upor, 2011, 35-37.

53. B. Repe, S puško in knjigo: narodnoosvobodilni boj slovenskega naroda 1941 1945, 2015, 360; I. Jan, Škof Rožman in kontinuiteta : zahteva po škofovi rehabilitaciji - ponoven izziv resnici, 1998, 404-407. 
the religious needs of the People's Liberation Army." Although this did not lead to the introduction of regular religious life in partisan units, religious officers were later present in all major Partisan units. In Styria, this role was performed by Pastor Jože Lampret, who was very popular among people because of his fight against social injustice and repression of peasants and workers. He joined the national resistance movement during his exile in Croatia and performed the oath through a religious service for all newcomers who joined the partisans. 1,200 fighters of the Rab Brigade, Tomšič Brigade, and Bračič Brigade gave their oath in the same manner. Father Lampret preached in churches, performed religious funerals of fallen Partisans, taught seminary in schools of the liberated territory of the Upper Savinja Valley, published articles in the Partisan press, and spoke on organized Partisan events. Bishop Rožman punished him by a suspension; officially due to masses without the Bishop's permission outside the given parish. ${ }^{54}$

On the other hand, priests weren't necessarily urged to join partisans in order to publicly demonstrate their opinion on the national liberation struggle. A prominent Slovenian Catholic philosopher, professor Dr. Janez Janžekovič (1901 - 1988), also included a paper Duty To The Nation (1941) into his extensive opus of articles (188 titles), where he marked national betrayal as a mortal sin:

"A national apostate is not only the ugliest traitor, but also a serious sinner from a religious standpoint. According to the Gospel, we know that anyone who lives by a sword shall die by the sword. From a national point of view, the MVAC is a treacherous organisation. It collaborates with the Fascists!"

Because of this writing, he had to defend himself from Bishop Rožman. ${ }^{55}$ Slovenian notable novelist and Pastor Fran Saleški Finžgar, who had already retired during the war, was warned by Bishop Rožman of the possibility of arrest by the Fascist authorities. Finžgar was bitterly disappointed with the degrading attitude of Slovenian authorities and official Church stance regarding the Italian occupation:

"They preferred to take the weapon, the outfit and the money from the invaders, to fight their own Slovenian brothers. This is the most devastating black stain in Slovenian history, which can not be erased by any excuse. A firm Christian conviction is understandable, so is a capitalist orientation, but incomprehensible and universally condemnable is the boldness of grasping for the weapon of a deadly national enemy to fight against your brothers. This is the pain of all pains."

He purposely kept into the isolation of his home, where he often gave vent to his indignation in front of students and colleagues who were visiting

54 I. Jan, Škof Rožman in kontinuiteta: zahteva po škofovi rehabilitaciji - ponoven izziv resnici, 1998, 143,158.

55. Ibid., 135-136. 
him. Consequently, he had to put up with continuous attacks from the Home Guard press and was also interrogated by the Italians. Despite his age and fragile health, he was active after the war: he edited publications and intervened on several occasions with the authorities for those who were targeted by the post-war regime. $^{56}$

These examples given, it is possible to discern the fact that the priests and faithful Catholics joined the national resistance mainly on the grounds, summed up by Dr. Mikuž with his own words:

"Either to stand on the side of honest people fighting for freedom or to step aside and watch resignedly from a peaceful corner thinking: whatever will be, it will be. This latter thing I could not do, for neither my human nor my priestly conscience would allow me that. It didn't take me long to reflect upon it when I learned how many fighters - Slovenians wish sincerely for a priest to be with them in their darkest hour of the separation of this world. And there is something else I could not ignore: could it be that this holy struggle for national freedom and a better future shall be won without mein Slovenia strong enough - the most ideal (or at least it should be) calling(profession) of a priest? I made my decision, and I joined. "

In principle, Bishop Rožman cannot be denied benevolence in talking to the Italian authorities for the sake of people who were sent to internment or otherwise. He had always maintained close contact with the Italian occupying authorities, to grant pardon to some people after their arrest. ${ }^{58} \mathrm{He}$ attended all Fascist manifestations, regardless of their importance. ${ }^{59}$ The official representatives of the Slovenian Catholic Church seriously followed decades old position of Bishop Mahnič, that faith was before nationality, and this position was best personified by Bishop Rožman, who was extremely active in his fight against communism. According to the testimonies of the priests at a Catholic Bishops' Conference, Bishop Rožman has clearly expressed the need for armed resistance against communism, namely with Italian arms. ${ }^{60}$

The most burdensome for Bishop Rožman, but also his most controversial role was his presence during the Home Guard oath. The collective oath of allegiance to the German forces took place at Ljubljana's central stadium on April 20th 1944, on Hitler's birthday. In their attempts to invoke his rehabilitation, his apologists claim that in the oath, Hitler is nowhere explicitly mentioned. The content of the oath caused much speculation and misrepresentation already in 1944, which surprised even Rožman himself. In his defense, he justified his presence during the oath ceremony by the fact that he performed the mass for the Home Guard recruits, because his diocese was still without its own Chaplains, and that no German soldier was

56. Ibid., 90,121,383.

57. T. Štefanec, Druga svetovna vojna - nasilje, žrtve, upor, 2011, 27-29.

58. T. Griesser-Pečar, Razdvojeni narod; Slovenija 1941 - 1945: okupacija, kolaboracija, državljanska vojna, revolucija, 2004, 176 - 180.

59. G. Krajnc, Hoja s hudičem: okupacija Slovenije in kolaboracija, 1941 - 1945, 2014, 89

60. Ibid., 104-105 
present during his own performance of religious service. Likewise, he argued that he had read the oath before the mass, to make sure the Slovenian Home Guard wouldn't swear their oath to Hitler, and ensured that in this case, he would not have performed the mass. ${ }^{61}$ The Chief Home Guard chaplain, Dr. Ignacij Lenček, emphasized that the clergy has worked hard to eliminate anything that might sound like loyalty to Nazism from the oath text:

"I swear by Almighty God that I will be faithful, brave and obedient to my superiors, that in the common war with the German armed forces, under the command of the leader of Great Germany, (the) SS units and the police, I will faithfully fulfill my duty to my Slovene homeland, which is a part of free Europe, against bandits and communism as well as their allies. For this I am prepared to sacrifice even my life. So help me God!",62

Bishop Rožman later claimed that he did not want to be present at the oath, and that he refused the invitation to the honorable guests' podium. The fact is that there were no German soldiers present at the stadium, but the oath ceremony began, before he cleared his gadgets. The Bishop pointed out that he had left the stadium without saying goodbye, as soon as his luggage was put into the car. In his reply to the trial in 1946, Bishop Rožman explained that he performed the mass before the oath at the specific request of the Home Guard personell and officers, and that he saw himself as a spiritual shepherd rather than a politician or diplomat. ${ }^{63}$

It was only after the war that Bishop Rožman realized how his attitude towards the occupying powers affected the civilian population. In 1946, he expressed his thoughts to Bishop Joe B. Žabkar in Rome in this manner: "All the contacts I have had with the Italians, I sincerely regret. All of them. I have not achieved one thing, haven't rescued not one hostage, prevented not one deportation, saved not even one house from arson fire, eased not one single suffering. Nothing, absolutely nothing. They always promised me everything, but never gave me anything. ${ }^{\prime 64}$

61. T. Griesser-Pečar, Razdvojeni narod; Slovenija 1941 - 1945: okupacija, kolaboracija, državljanska vojna, revolucija [A torn nation; Slovenia 1941 - 1945: occupation, collaboration, civil war, revolution](Ljubljana: Mladinska knjiga Press, 2004), 307.

62. "The Home guard has sworn fidelity to its homeland," Slovenec, no. 91(April 21st 1944): 2.

63. G. Krajnc, Hoja s hudičem: okupacija Slovenije in kolaboracija, 1941 - 1945, 2014, 232; T. Griesser-Pečar and F. M. Dolinar, Rožmanov Proces [The Rožman Trial] (Ljubljana: Družina 1996), 137; T. Griesser-Pečar, Razdvojeni narod; Slovenija 1941 1945: okupacija, kolaboracija, državljanska vojna, revolucija, 2004, 306 - 307.

64. M. Žnidarič, Slovenci v primežu okupacije, kolaboracije in osvobodilnega boja v letih 1941 - 1945 [Slovenes inbetween the occupation, collaboration and national liberation movement in years 1941 - 1945], in Škof Rožman v zgodovini, ed. J. Pleterski (Ljubljana: Društvo piscev zgodovine NOB Slovenije - The Association of the Slovenian National Liberation Front History Writers, 2008): 22 


\section{Discussion and Conclusion}

Because of its archaic perception of the world that no longer wanted to function within the "natural order and will of God," the Slovenian Catholic Church found it extremely difficult to tolerate the fact that the laity had become an equivalent counterpart or rival. Despite the apparent accommodation in the public discourse, the Church representatives were rather unable or unwilling to adapt to the new social changes, which ultimately resulted in tragic consequences. This was especially evident in their rejection of everything linked to liberalism and communism; this kind of inflexibility had ultimately seduced orthodox Catholicism messengers into national betrayal. Driven by fear of "Godless bandits", it wasn't just the White Guard and Home Guard members who committed crimes like rape, arson, torture, murder, and helping the occupier with deportations of the civilian population into labor and concentration camps. Some of their spiritual leaders also participated in these atrocities, to underline their sermons from the pulpits more efficiently. The Slovenian bibliography of these atrocities is rather vast and backed up with original documents of correspondence between the Home Guard, priests involved in particular killings, and the occupier, along with some gruesome photographs that survived the deliberate destruction of burdensome material. There are numerous written and recorded testimonies of victims' relatives and survivors; some of them already collected records and data for later processing during the war.

Paranoid over losing its influence and over any social change that Communism was just about to present at the time, the Slovenian Church struggled to defend its identity especially in preserving ideological continuity. This is why the Slovenian Church lost the ability to use ethical criteria and basic humanity as key Christian principles when making decisions in critical times of occupation. With much debated and mourned spillover of fraternal blood, though, the Catholic apologists somehow fail to analyze the coresponsibility of their own party, which, according to all applicable standards, served the occupying Axis forces. The Home Guard oath in particular clearly states that the Home Guard swore an oath of allegiance to the Leader of Greater Germany, which obviously could not be any other than Hitler. Given the fact that Bishop Rožman himself confirmed in his own words, that he had read the text of the oath before the ceremony, the arguments that this was not an oath to Hitler, cannot be characterized as anything else than hypocrisy. ${ }^{65}$ From everything presented, it is obvious that the official Catholic Church in Slovenia today is not objectively able to take responsibility for their role in the collaboration during World War. The documentation that confirms the direct or indirect involvement of clergy in atrocities of the occupier has been pushed aside due to the current social climate, but it's still extensive and accessible to everyone.

The Catholic Church overall committed a fatal error in teaching that Communism was a greater threat than Nazism, either to the Church itself, or to the humanity in general. Such a position, however, does not stand a

65. T. Griesser-Pečar and F. M. Dolinar, Rožmanov process, 1996, 136. 
reasonable assessment, because it ignores the significant difference between the ideologies compared. Communism essentially dealt with the social, economic and, consequently, class changes in society. A real threat to the Slovenian nation (and many others), however, was a physical and ethnic disappearance, planned by Hitler, Mussolini, and their supporters. Therefore, Fascism and Nazism left no other alternative but armed resistance by Slovenes and all people elsewhere in Europe - not if they wanted to survive on their land.

After the general collapse of Communism, and Slovenia gaining its independence, a positive side to the democratization in this country has been not only the discussion, but also the condemnation of illegal post-war killings. At least some victims also received a decent burial. But there is another side of the coin as well. First and foremost, it is necessary to recognize and condemn the war crimes in the name of religion, which were indisputably demonstrated in the service of the Axis forces by the "soldiers of Christ" against their own nation. If Nazism and Fascism are recognized as two genocidal ideologies, the voluntary assistance to the Nazi and Fascist occupation forces should also be recognized as genocidal.

In the Slovene public and political discourse, the topic of this research is higly relevant, for it is repeatedly adressed and abused; the dominant right-wing political parties (SDS and NSi in particular) are being extremely aggressive and persistant on the matter before elections. Just this year, prior to Slovenian Parliamental elections in June, the right wing oriented Institute for patriotic values (Inštitut za domoljubne vrednote) adressed Zoran Janković, the mayor of Slovenian capital city Ljubljana, with the demand to prevent the concert "Nosil bom rdečo zvezdo" (I shall wear the red star) from taking place on the Congress square on May 25th (which used to be celebrated as Tito's birthday). The demand is based upon the opinion that the red star is merely a symbol of an non-democratic and totalitarian regime, and as such isn't compatible with the Slovenian constitution. In his stern reply, the mayor of Ljubljana stated that it was the Partisans with red stars who freed the country, and reassured: "Even if you bring your wanna-be-patriots to Ljubljana, to intimidate the citizens, I assure you that at the moment you express hatred, this city will exclude you, embarrass you and turn its back on you. This is how much I believe in the nobility of this city. It is sad enough and embarassing for the country of Slovenia, that your outbursts of hatred in some other municipalities went by unpunished. This will not be so in Ljubljana." ${ }^{66}$

The ideological differences arising from the past mostly serve for soliciting a certain electoral base. Just like their predecessors before and during the $2^{\text {nd }}$ World War, modern right-oriented Slovenian parties faithfully preserve the tradition of loud accusations. According to the most persistant right-wing politicians, the Slovenian political left wing does not pay enough respect to the victims of post-war killings. This opinion is regularly backed up by highest Church officials in Slovenia. On July 13th in 2017, the Slovenian President Borut Pahor laid a wreath in front of a newly built monument at the Congress Square in Ljubljana. But this did not calm down the present apologists of the

66. V. Brkič, Mesto vam bo obrnilo hrbet [The city will turn its back on you], Dnevnik, April 18, 2018, https://bit.ly/2Kpsf6Y. 
Home Guard, who united their forces within the organization Nova Slovenska Zaveza (The New Slovenian League). They argue that until the Home Guard struggle is given proper legitimacy and the criminal essence of the revolution is recognized and condemned, there will be no reconciliation. The now deceased Archbishop Dr. Franc Perko stated that " there are many true martyrs in the Kočevje caves, who resisted the violent communist revolution to defend their faith, their lives and Christian values of the Slovene nation". And yet he could not say a word about crimes commited by the very mentioned Home Guards in the mass graves. ${ }^{67}$ Thus, the historical reconciliation of 1990 is viewed only as a manipulation for the larger auidence, while the assassinated Home Guards took the role of martyrs for the Christian faith. The papal nuncio Santos Abril y Castello, who visited Slovenia in 2009, backed up these statements even to the point where Slovenian President Danilo Türk had to remind him of the good manners in diplomacy: the President pointed out "an indefinite sermon as unfit for the diplomatic representative of the Vatican" and advised him to be more sensitive to Slovenian history. ${ }^{68}$

Personally, I believe that reconciliation is possible, but this requires the overcoming of deeply ingrained phylosophical patterns that are typical for Catholic political activism, which denies everything outside the narrow framework of the Catholic religion, society and interpretation of morality. While taking the splinter out of the counterpart ideology eye, the present Slovenian Catholic Conservatives consciously reject the taking of timber from their own eye first. Had the crucial high Church officials policy been able to understand the danger of Nazism before Communism on time, many victims of Nazism and Fascism could have survived. This being said, it is of necessary to consistently distinguish between official Church policy and those priests inside or outside the Liberation Front, who saw the fulfillment of Jesus' teachings in the underground rebellion against the occupier. It is important to remember that the attitude of the Slovenian clergy varied from province to province, with priests in the Littoral (Primorska) region playing a crucial role in preserving the nation's cultural identity.

When trying to sum up the core of the problem, it really comes down to the fact that the secularization of Slovenian society has reached the point of no return, and representatives of Catholic doctrine should strongly consider this in their attempts to regain the main position in public spheres of politics, education and society. Furthermore, the Slovenian Church authorities should be able to define more specifically their attitude towards those believers and priests, who supported and joined the national resistance, and who proved with their own example that the issue of ethnic existence and survival is also a question of survival of Christian principles as generally represented by the official Church. In the long run, this would mean a peculiar adaptation of Catholic political activism. This may not be pleasant to the apologist historians who stretch their imagination to the extreme, in order to justify the morally

67. M. Horvat, "Brezno razdora: še ena ne-spravna slovesnost v Kočevskem Rogu" ["An abyss of disagreement: another non-conciliation ceremony in Kočevski Rog"], Mladina, July 7, 2010 https://bit.ly/2jWDOal.

68. Ibid. 
questionable decisions of the Church in the recent history. To what extent is the Slovenian Catholic society ready for this kind of sincerity, it is yet another matter. In the current situation, the answer to this question appears to be hidden in a rather distant future.

This paper is supposed to join the minority of those in the Slovene territory who try to get past the ideological rhetoric war that had reached its' peak more than 70 years ago. Instead, it focuses on the interaction between some clergy and the occupiers when searching for links between causes and consequences for the emergence of a civil war in parallel with the liberation war against Nazism and Fascism. Despite the unambiguous position on the necessity of armed resistance, there is no avoiding its' dark sides. Same goes for the positive woes and actions of Bishop Rožman. The author agrees with those historians who point out the ideologically motivated procedural errors in post-war trials. For a further investigation on the same topic, the author would like to encourage a wider debate among European historians, in order to compare experiences in different countries on how churches interacted with national resistance forces on one hand and the occupiers on the other hand. There are also many possibilities for exploring and analyzing the specific situations of the Church collaboration. For a more detailed in-depth study of ideological flows within the Catholic Church, it would be advisable to devote particular attention to those priests who worked in the armed anti-fascist committee, which resulted in partial or complete opposition to the official Doctrine of the Vatican. This may also encourage the present Catholic Church to open dialogue, which could help the very Church in cleaning its' very stain of silent tolerance of Nazi-imperialism.

An additional novelty of the investigation is that this paper offers an interesting insight into specifics of Slovenian local particularism, to a larger European community, in order to encourage a research on points of contact with other social dilemmas in the remaining European countries. Some historians believe that the revision of history is a pan-European trend. Conservative parties are dominating the EU, and in Eastern European countries there is an increasing number of institutions for the study of totalitarianism, who seem to justify their existence with ideological cleansing. The revision of modern European history is carried out by demonizing Communism and rehabilitating collaborationism, which brings the society to relativizing what German Nazism has done to Europe and the world because of its ideology. The Slovenian share of this jigsaw puzzle may not be as pathological as it seems at first glance. But this is a matter of the multilateral debate of historians, not of ideologists. ${ }^{69}$

69. B. Repe, "Rovte s pomenljivim imenom niso le slovenske, pač pa tudi evropske" ["Rovtes with a meaningful name are not only Slovene, but also European"]. Mladina, August 8, 2013. https://bit.1y/2wFZNeS. 


\section{Bibliography}

Brkič, V. Janković: Mesto vam bo obrnilo hrbet [The city will turn its back on you]. Dnevnik, April 18, 2018. https://bit.ly/2Kpsf6Y.

Davies, P. Nevarna razmerja: kolaboracija in druga svetovna vojna [Dangerous Liasions: Collaboration and World War Two]. Ljubljana: Modrijan Press, 2010.

Ferenc, T. Nacistična raznarodovalna politika v Sloveniji v letih 1941-1945 [The Nazi national and assimilation politics in Slovenia in the years 1941-1945]. Maribor: Obzorja Pres, 1968.

Ferenc, T. Okupacija slovenskega ozemlja [The Occupation of Slovenian Territory], in Slovenska novejša zgodovina 1848 - 1992, edited by J. Fischer (Ljubljana: Institute of Contemporary History, 2005), 581-601

Ferguson, N. The War of the World: Twentieth Century Conflict and the Descent of the West. New York: Penguin, 2007.

Grgič, S. Zločini okupatorjevih sodelavcev, monografija v treh knjigah.1. knjiga: izven borbe pobiti in na druge načine umorjeni, ranjeni in ujeti slovenski partizani [The crimes of the occupier's assistants - monograph in three books. Book 1: killed outside the battle and otherwise killed, wounded and captured Slovenian Partisans]. Novo mesto: Društvo piscev zgodovine NOB Slovenije; Tiskarna Novo mesto, Dolenjska založba, 1995.

Griesser-Pečar, T. Razdvojeni narod; Slovenija 1941 - 1945: okupacija, kolaboracija, državljanska vojna, revolucija [A torn nation; Slovenia 1941 - 1945: occupation, collaboration, civil war, revolution]. Ljubljana: Mladinska knjiga Press, 2004.

Griesser-Pečar, T. and Dolinar F. M. Rožmanov Proces [The Rožman Trial]. Ljubljana: Družina 1996.

Horvat, M. "Brezno razdora: še ena ne-spravna slovesnost v Kočevskem Rogu" ["An abyss of disagreement: another non-conciliation ceremony in Kočevski Rog"]. Mladina, July 7, 2010. https://bit.ly/2jWDOal.

Jan, I. Škof Rožman in kontinuiteta : zahteva po škofovi rehabilitaciji - ponoven izziv resnici [Bishop Rožman and continuity: the demand for Bishops' rehabilitation - a new challenge to the truth]. Ljubljana: self published, 1998.

Klemenčič, M. and Žagar M. The former Yugoslavia's diverse peoples: a reference sourcebook. Santa Barbara, California: ABC Clio, 2003.

Kos, J. "Druga pričevanja" ["Other testimonies"]. In Škof Rožman v zgodovini, edited by J. Pleterski. Ljubljana: Društvo piscev zgodovine NOB Slovenije - The Association of the Slovenian National Liberation Front History Writers, 2008.

Krajnc, G. Hoja s hudičem: okupacija Slovenije in kolaboracija, 1941 - 1945 [Walking with the Devil: Slovene Collaboration and Axis Occupation, 1941 - 1945]. Mengeš: Ciceron, 2014.

Kučan, M. "Spravna slovesnost v Kočevskem Rogu." ["Conciliation ceremony in Kočevski Rog"]. Milan Kučan arhivska stran. July 8, 1990. https://bit.ly/2Ky wSpu.

Kucler, S. B. "Slovenians are too immature for politics: the conversation with dr. Anton Trstenjak, a psychologist-researcher and theologian, author of numerous scientific and popular books that decisively shaped the level of cultural consciousness of Slovenes during the decades after the Second World War." Glas Slovenije, no. 28(1994): 9.

Mahnič, A. "Revolucionarno gibanje na Ruskem" ["Revolutionary movement in Russia"]. Rimski Katolik, no. 1(1891): 286.

Mahnič, A. "Slovstvo" ["Language"]. Rimski Katolik, no.1(1889): 418 
Mahnič, A. "Brezglavnost slovenske politike- posnemajmo češke katoličane!" [The headlessness of Slovenian politics - let's take the Czech catholics' example!]. Rimski katolik, no.1(1891): 84.

Pančur, A. Leto 1848 in oblikovanje programa Zedinjena Slovenija [The year 1848 and the forming of the programme Unified Slovenia] (Ljubljana: Institute of Contemporary History, 2005), 24- 31.

Pelikan, E. Akomodacija ideologije političnega katolicizma na Slovenskem [The accommodation of the political Catholicism' ideology on Slovenian soil]. Maribor: Obzorja Press, 1997.

Pust, A. Palme mučeništva: ubiti in pomorjeni slovenski duhovniki, redovnii in bogoslovci in nekateri verni laiki [Zdravko Reven and Božidar Slapšak, Palm trees of martyrdom: killed and murdered Slovenian priests, monks and theologians and some religius laics]. Celje: Mohorjeva družba Press, 1994.

Repe, B. S puško in knjigo: narodnoosvobodilni boj slovenskega naroda 1941 -1945 [With a rifle and a book :the national liberation struggle of the Slovenian nation 1941 - 1945]. Ljubljana: Cankarjeva založba Press, 2015.

Repe, B. "Rovte s pomenljivim imenom niso le slovenske, pač pa tudi evropske" ["Rovtes with a meaningful name are not only Slovene, but also European"]. Mladina, August 8, 2013. https://bit.ly/2wFZNeS.

Saje, F. Belogardizem [The White Guard]. Mengeš: Ciceron Press, 2008.

Štefanec, T. Druga svetovna vojna - nasilje, žrtve, upor [Second World War: violence, victims, rebellion]. Ljubljana: self-published, 2011.

"The Home guard has sworn fidelity to its homeland." Slovenec, no. 91(April $21^{\text {st }}$ 1944): 2.

Toš, N. et al. Vrednotenje preteklosti [Evaluation of the past]. http://www.cjm.si/? $\mathrm{q}=$ publikacije.

Vidic, J. Po sledovih Crne roke [Following the traces of the Black Hand]. Ljubljana: Borec Press, 1975.

Žnidarič, M. "Slovenci v primežu okupacije, kolaboracije in osvobodilnega boja v letih 1941 - 1945" ["Slovenes inbetween the occupation, collaboration and national liberation movement in years 1941 - 1945"]. In Škof Rožman v zgodovini, edited by J. Pleterski. Ljubljana: Društvo piscev zgodovine NOB Slovenije - The Association of the Slovenian National Liberation Front History Writers, 2008: 22. 
